\title{
State of the Art of Electricity Generation (2007-2017)
}

\author{
Diana Enescu ${ }^{1}$, Giovanni Vincenzo Fracastoro ${ }^{2}$, Bruno Panella $^{2}$ and Filippo Spertino ${ }^{2, *}$ \\ ${ }^{1}$ Valahia University of Targoviste, Electronics, Telecommunications and Energy Department, Targoviste, Romania \\ ${ }^{2}$ Politecnico di Torino, Dip. Energia, corso Duca degli Abruzzi 24,10129 Torino, Italy
}

\begin{abstract}
The statistics for world energy consumption and electricity production in the last decade are presented to highlight the increment of the electricity share, compared to thermal usages and transportation, in the energy sector. The main technologies for electricity production from fossil fuels and nuclear power are summarised, indicating their characteristics, current plants, and emerging trends. Finally, the state of the art, regarding the technical applications of photovoltaic (PV) generators and wind turbines (WT), is presented.
\end{abstract}

\section{Statistics of energy production and consumption}

There is general concern about climate change and general agreement on its causes. The use of fossil fuels for electricity production, road transportation, and heating buildings is by far the most important of these causes. COP 21 in Paris (2015, [1]) for the first time described a general agreement and paved the way for concrete actions which should be undertaken to mitigate climate change.

While we are still waiting for such actions to become real, it might be useful to examine the trends in energy consumption during the past decennium (2007-2017), the most recent for which reliable statistical data set is available, with a special focus on electricity production. The following data set (Fig.s 1 through 5) has been extracted and re-elaborated from Enerdata (2019, [2]).

Global energy consumption has grown from 11.7 to 13.6 billion tons of oil equivalent (toe), showing a $+16.2 \%$ growth (Fig. 1 CO2 emissions have consequently also grown, from 28,300 to $32,600 \mathrm{Gt}$, an increase of $15.2 \%$, slightly lower than the global consumption increase (Fig. 2).

The reduction of emissions in Europe, CIS and the Americas (-6\%, from 14.6 to $13.7 \mathrm{Gt}$ ) has been largely offset by the $38 \%$ growth in Asia, from 11.1 to $15.3 \mathrm{Gt}$.

In the same decennium, global electricity production has grown from 17,100 to $22,000 \mathrm{TWh}$, a rate of $29.8 \%$, almost double that of global energy consumption (Fig. $3)$.

The increasing electrification of the world economy has been accompanied by a growing contribution from renewable sources, which is one of the key actions in reducing carbon emissions. In the 2007-2017 decennium the installed capacity increased from about 1000 to 2195 GW (+120\%), mainly thanks to the so-called "new RES" (renewable energy sources, i.e., photovoltaics and wind), which increased their capacity from 100 to $942 \mathrm{GW}$
(REN21, 2018, [3]). Accordingly, the estimated electricity produced by renewables has grown from 3500 to over $6200 \mathrm{TWh}$, as seen in Fig. 4, which distinguishes hydroelectricity, geothermal and biomass, solar and wind energies. The share of renewables in electricity production has increased from $17.7 \%$ to $24.3 \%$. Almost half of the electricity production increase is due to renewables.

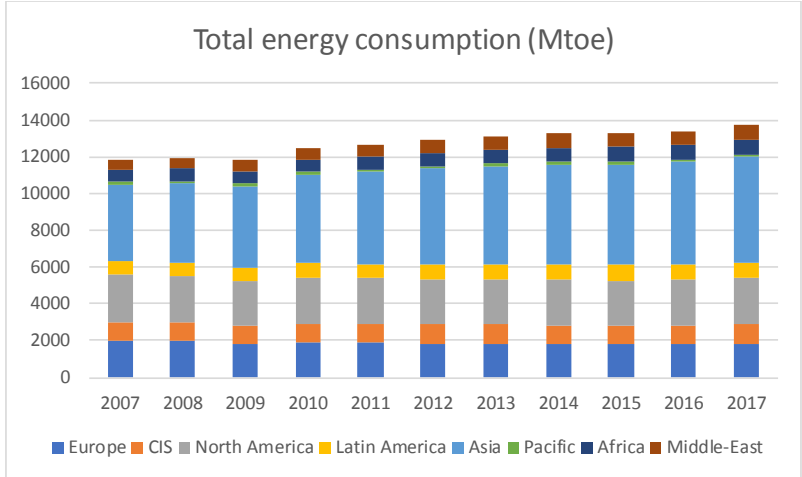

Fig. 1. Total energy consumption per area (2007-2017).

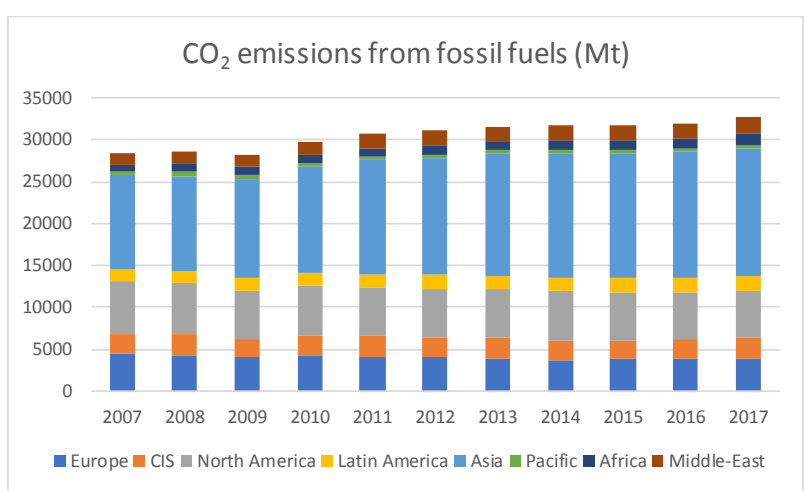

Fig. 2. Total CO2 production per area (2007-2017).

\footnotetext{
Corresponding author: filippo.spertino@polito.it
} 


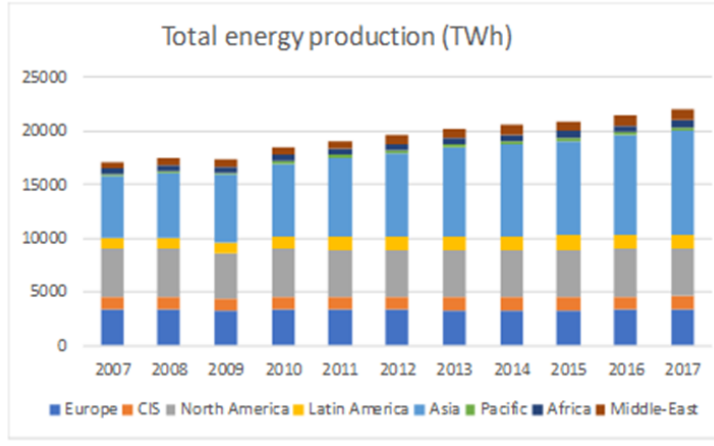

Fig. 3. Electricity production per area (2007-2017).

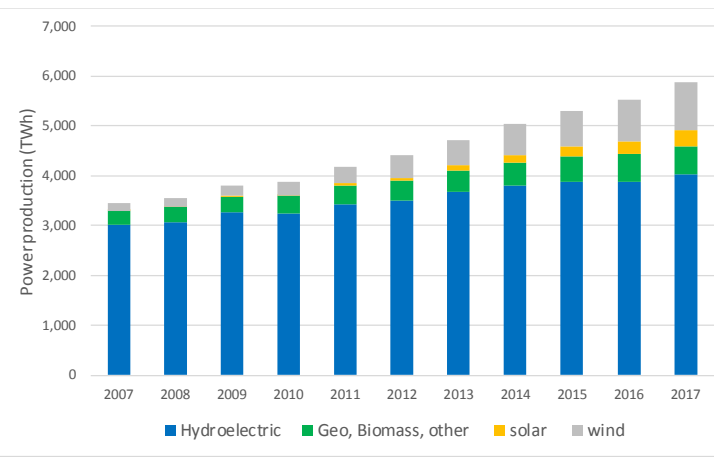

Fig. 4. Electricity production from RES according to technology (2007-2017).

A closer examination of RES production is provided in BP statistics [4], which include a more detailed list of countries than [1]. It is worth noting that BP statistics do not include municipal solid waste and pumped hydro. Furthermore, in the last decade PV and WT generators have increased their production eight-fold, from slightly below 200 TWh to almost 1600 TWh (Fig. 5). In 2007 their share of the overall electricity production was only $0.9 \%$ (and $5.0 \%$ of renewables), in 2017 they had reached $6.1 \%$ of the overall electricity production and $25.2 \%$ of the renewables.

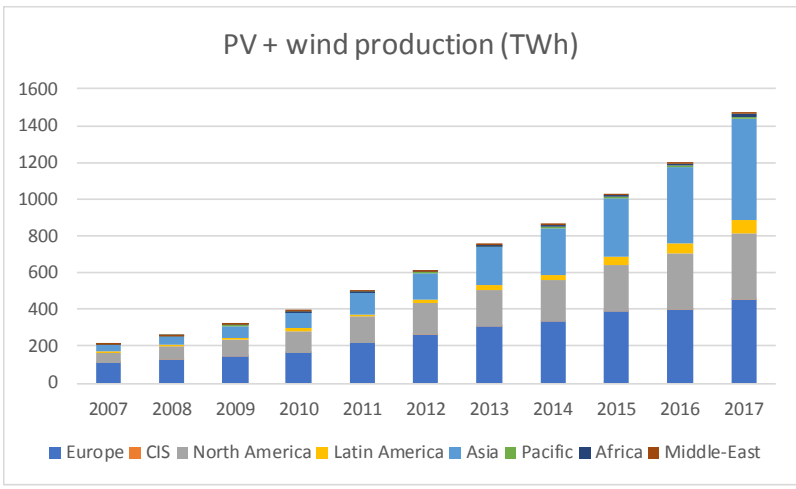

Fig. 5. Electricity production from $P V$ and wind generators (2007-2017).

At a country level, Fig. 6 shows the top 20 countries according to the share of RES. It should be noted that the two top countries (Norway and Colombia) owe their position in this ranking almost exclusively to hydroelectricity. Then, more than half of the RES share in Denmark, Portugal, Germany, Spain, the UK and
Belgium is due to PV and WT generators. Under the point of view of PV and WT, the top 20 countries are shown in Fig. 7. Denmark is by far \#1, with almost $45 \%$ of its electricity generated by wind (and a negligible contribution from PV). The countries following Denmark in this ranking (New Zealand, Spain, Germany and Portugal), hardly reach half of its share.

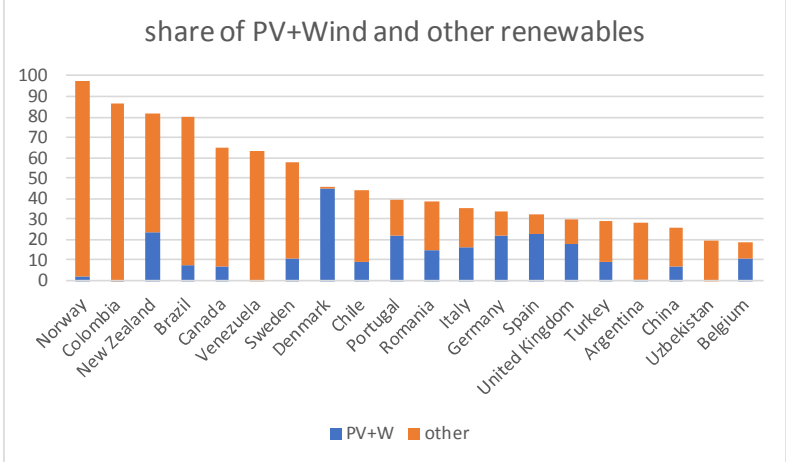

Fig. 6. Top 20 countries according to RES share in electricity production (2017).

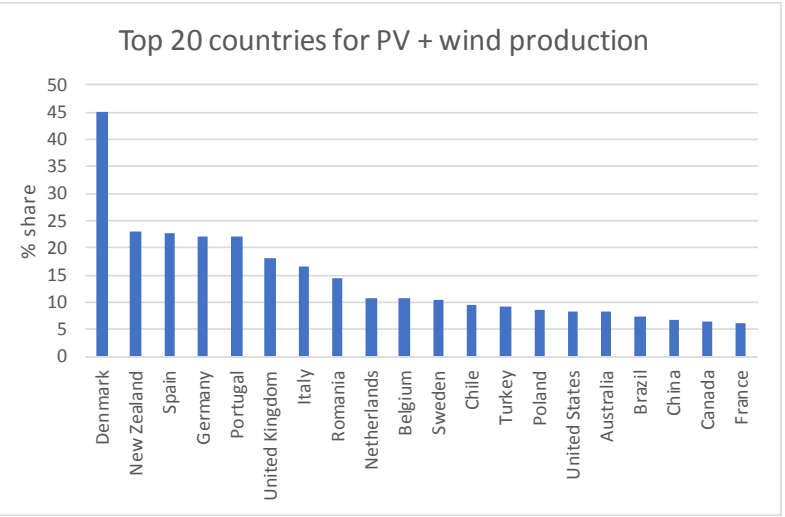

Fig. 7. Top 20 countries according to $(\mathrm{PV}+\mathrm{WT})$ share in electricity production (2017).

\section{State of the art of fossil fuel power plants}

Various studies indicate that in many scenarios the dominant role of conventional fossil fuels will not be modified in the near future [5]. The International Energy Agency (IEA) presented two scenarios in the World Energy Outlook 2018 [6]. The New Policies Scenario (NPS) is based on existing and announced energy policies, while the Sustainable Development Scenario (SDS) is based on reaching objectives of climate change, air quality and global access to energy. The main difference between these scenarios for 2017 to 2040 is that electricity generation from coal sources remains almost stable in the NPS, but reduces considerably in the SDS. Electricity production from natural gas has a relative increase in the NPS and a slight reduction in the SDS. The share of electricity production from oil remains limited compared to the other sources and decreases over time (more markedly in the SDS).

Today, coal-fired power generation has the largest share $(37 \%)$ among the electricity generation sources 
worldwide [7]. In recent years, coal-fired power generation has increased in Asia (mainly in China and India), but decreased in Europe and in the US. Overall, after a reduction in 2015 and $2016(-2 \%$ and $-3 \%$, respectively), there was a growth of $3 \%$ in 2017. Some countries have announced that they will phase out coal (for example, by 2025 in the UK).

Phase-out of coal has been announced in some countries (by 2025 in the UK).

The technologies that generate electricity from fossil fuels are classified according to (Fig. 8):

- the type of fuel used (coal, lignite, natural gas or oil);

- the conversion process from fuel chemical energy to thermal energy;

- the electricity generation stage, in which different types of turbines (gas turbine or steam turbine) are used to drive the electrical generator [8].

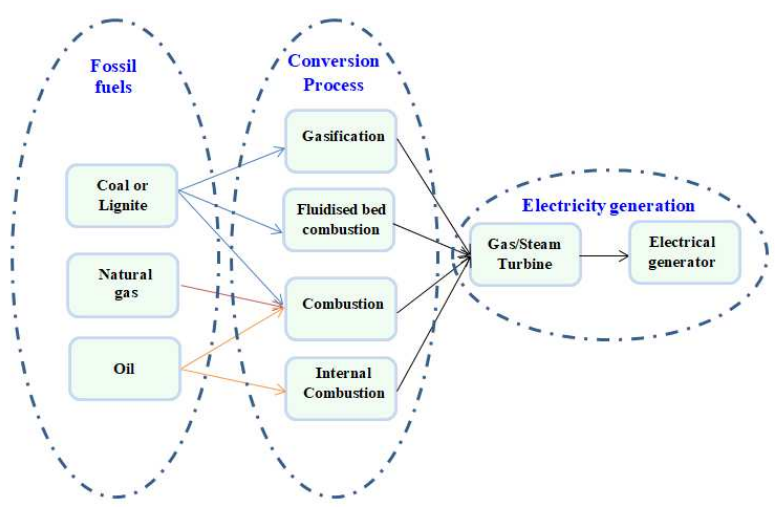

Fig. 8. Technologies that generate electricity from fossil fuels.

Table 1 presents some advantages and limitations of power generation technologies that use coal, gas and oil [9]. Since oil is less preferred for power generation than coal and gas, the following sub-sections specifically address coal and gas power plants.

Solutions aimed at enhancing the efficiency of the thermodynamic cycles used for power generation, and the development of carbon capture and storage units, have to be promoted [10].

Table 1. Advantages and limitations of power generation technologies.

\begin{tabular}{|l|l|l|}
\hline Technology & Advantages & Limitations \\
\hline Coal & $\begin{array}{l}\text { Low-cost } \\
\text { energy source in } \\
\text { some countries }\end{array}$ & $\begin{array}{l}\text { Reduced efficiency, } \\
\text { high } \mathrm{CO}_{2} \text { emissions, } \\
\text { suitable for baseload } \\
\text { power supply }\end{array}$ \\
\hline Gas & $\begin{array}{l}\text { Flexible power } \\
\text { supply }\end{array}$ & Cleaner than coal \\
\hline Oil & $\begin{array}{l}\text { High energy } \\
\text { density, suitable } \\
\text { for mobile } \\
\text { applications }\end{array}$ & $\begin{array}{l}\text { Less preferred for } \\
\text { power generation }\end{array}$ \\
\hline
\end{tabular}

\subsection{Coal power technologies}

Pulverised coal combustion (PCC) is the most widely used technology in coal-fired power plants worldwide. The efficiency of a PCC plant depends on coal quality, environmental conditions, steam conditions, plant design, and operation and maintenance [11]. The thermal efficiencies of power plants have increased in recent decades by increasing the steam temperature and pressure. Control of the combustion is very efficient in steady-state operation, although there are some issues in transient operation [12]. The coal fired power generation technologies are divided into subcritical, supercritical (SC) and ultra-supercritical (USC) technologies, based on the differences in pressure and temperature. Subcritical cycle plants can be divided into small-sized $(<50 \mathrm{MW})$ and mid-sized plants (about $300 \mathrm{MW}$ ). Supercritical cycle plants are large-scale technologies (about $500 \mathrm{MW}$ ). Subcritical and supercritical power plants represent more than $95 \%$ of global capacity (about $80 \%$ is subcritical technology and about $15 \%$ is supercritical) [13].

The approximate temperature and pressure ranges, together with the efficiencies of the coal power units, are shown in Table 2 [14]. SC and USC technologies have higher operational efficiency compared to subcritical power plants leading to lower fuel consumption and $\mathrm{CO} 2$ emissions. In Europe, the efficiencies are based on the lower heating value (LHV) of the fuel, while in the US they are based on the higher heating values (HHV) of the fuel. In general, efficiencies based on LHV are higher than those based on HHV, and so the US efficiencies are lower with $2 \div 4 \%$ than the European efficiencies).

Table 2. Features of Subcritical, Supercritical, and Ultrasupercritical Power Plants.

\begin{tabular}{|c|c|c|c|c|}
\hline $\begin{array}{c}\text { Type of } \\
\text { plant }\end{array}$ & $\begin{array}{c}\text { Main } \\
\text { Steam } \\
\text { Pressure } \\
\text { (bar) }\end{array}$ & $\begin{array}{c}\text { Main Steam } \\
\text { Temperature } \\
\left({ }^{\circ} \mathbf{C}\right)\end{array}$ & $\begin{array}{c}\text { Reheat } \\
\text { Steam } \\
\text { Temperature } \\
\left({ }^{\circ} \mathbf{C}\right)\end{array}$ & $\begin{array}{c}\text { Efficiency } \\
\text { based on } \\
\text { HHV } \\
(\%)\end{array}$ \\
\hline Subcritical & $\begin{array}{c}<221 \\
\text { bar }\end{array}$ & up to $565{ }^{\circ} \mathrm{C}$ & up to $565{ }^{\circ} \mathrm{C}$ & $33 \div 39 \%$ \\
\hline Supercritical & $\begin{array}{c}221 \div 250 \\
\text { bar }\end{array}$ & $540 \div 580{ }^{\circ} \mathrm{C}$ & $540 \div 580{ }^{\circ} \mathrm{C}$ & $38 \div 42 \%$ \\
\hline $\begin{array}{c}\text { Ultra- } \\
\text { supercritical }\end{array}$ & $\begin{array}{c}>250 \\
\text { bar }\end{array}$ & $580{ }^{\circ} \mathrm{C}$ & $580{ }^{\circ} \mathrm{C}$ & $>42 \%$ \\
\hline
\end{tabular}

The integrated gasification combined cycle (IGCC) and circulating fluidised bed combustion (CFBC) are other advanced coal-fired power generation technologies or cleaner coal technologies (CCTs).

IGCC is the most advanced precombustion technology and includes a combination of two different technologies (coal gasification and combined cycle) [15]. IGCC operates with efficient high-temperature gas turbines and is highly efficient [14].

CFBC is the prevalent type of FBC for power generation. CFBC plants use bed materials (e.g. silica sand) for the pulverised coal combustion or solid fuels (at temperatures of about $900^{\circ} \mathrm{C}$ ) to produce heat. The steam produced inside the combustor is used to generate power in steam turbines [16]. CFBC offers specific advantages over PCC, due to the mixture of coal with other fuels, including waste and reduced quality coals. 
One of the current proposals is to develop carbon capture and storage (CCS) as a new "clean coal" technology. CCS has environmental benefits, but has an impact on the efficiency of the thermal power plants. The methods used to capture $\mathrm{CO} 2$ in power plants are post-combustion, pre-combustion and oxy-fuel combustion [17].

\subsection{Gas power technologies}

The gas power plants based on F-class heavy-duty gas turbines (HDGT) are the most diffuse today at large scale (about 170-300 MW in the simple cycle, and about $450 \mathrm{MW}$ in combined cycles). These turbines have firing temperatures of $1300-1400{ }^{\circ} \mathrm{C}$. In spite of their good availability and reliability, in the period from 2010 to 2015 the increase in their diffusion has been lower than for advanced G-, H- and J-class gas turbines [18].

The most effective solution for large-scale electricity generation is the natural gas combined cycle (NGCC) power plant, in which a gas turbine "topping" cycle provides the heat to supply a steam "bottoming" Rankine cycle. NGCC solutions can achieve combined cycle efficiencies of over $60 \%$ with respect to the LHV.

Supercritical $\mathrm{CO} 2$-based power cycles (sCO2) are being studied for power generation applications with combined cycles. The $\mathrm{sCO} 2$ power cycle can be used as a "topping" cycle in fossil fuels power plants, or as a "bottoming" cycle in gas combined cycle power plants.

Aero-derivative gas turbines have been effectively used in single cycles for small-scale applications, although their application in combined cycles has not found acceptable convenience yet.

For small-scale applications, combined heat and power solutions use natural gas-fired internal combustion engines and microturbines.

\section{State of the art of PV and wind power plants}

The technical progress of photovoltaic (PV) technologies can be summarised in terms of conversion efficiencies of the commercial unit, that is, the PV module, which incorporates dozens of solar cells encapsulated to prevent damage from environmental agents (snow, hail, wind, UV rays and dust). Technical improvement in the wind turbine (WT) technologies is represented by enlargement in the diameters of turbines with three-blade horizontal-axis rotors.

The current situation regarding the conversion efficiencies of the PV modules for applications at ground level (satellite applications are not considered here) is discussed in the following. The innovative monocrystalline silicon technologies have the highest efficiency (about 22\%) with an improvement of $30 \%$ in the last 9-10 years. On the other hand, the thin films of cadmium telluride and copper-indium-gallium-diselenide reach efficiencies of $15 \%$, with improvements of about $50 \%$. The most widespread technology is polycrystalline silicon technology with efficiencies of $16-$ $17 \%$. The values of efficiency are almost constant for a wide range of solar irradiance, from $0.2 \mathrm{~kW} / \mathrm{m} 2$ to 1 $\mathrm{kW} / \mathrm{m} 2$. A specific property of the PV technology is its modularity, which permits the rated power of a PV module $(360 \mathrm{~W})$ to scale up to the rated power of PV generators of several hundreds of kilowatt that feed the input of the power conditioning units (DC-AC converters or inverters).

In ten years (from 2005 to 2015) the typical diameters of commercial wind turbines increased by $40 \%$, from $125 \mathrm{~m}$ to $180 \mathrm{~m}$, with a remarkable increment in hub height. The corresponding rated powers increased from $5 \mathrm{MW}$ to $10 \mathrm{MW}$ for typical offshore applications. The conversion efficiencies are strongly variable according to the wind speed values. WT efficiencies, around $45-50 \%$, at relatively low wind speeds of 5-10 $\mathrm{m} / \mathrm{s}$ can be much higher than PV generator efficiencies. Nevertheless, the same efficiencies become relatively low $(<10 \%)$ at high wind speeds of $20-25 \mathrm{~m} / \mathrm{s}$.

\section{State of the art of PV and wind power plants}

This article presents statistics regarding world energy consumption and electricity production in the last decade, focusing on electricity production, which tends to be prevalent in the energy sector, with respect to heat and transportation usages, because electricity is easy to manage and transmit over long distances. Various technologies, based on fossil (coal and gas power plants) and nuclear (that is carbon-free) fuels, were described in terms of configurations, sizes, performance and future trends. Solar photovoltaic and wind generators are making significant contributions to electricity production globally.

\section{References}

1. COP21 website of the publications [Online]. Available: www.wri.org/parispubs [Access date: 9 May 2019].

2. Enerdata website [Online]. Available: http://yearbook.enerdata.net/total-energy/worldconsumption-statistics.html [Access date: 9 May 2019].

3. REN21 website of the publications [Online]. Available:http://www.ren21.net/resources/publicatio ns/ [Access date: 9 May 2019].

4. BP Statistics website of world energy [Online]. Available:www.bp.com/en/global/corporate/energyeconomics/statistical-review-of-world-energy.html [Access date: 9 May 2019].

5. X. Wu, J. Shen, Y. Li, K.Y. Lee, WIREs Energy and Environment, 4(6), 537-563 (2015)

6. International Energy Agency, World Energy Outlook 2018 [Online]. Available: https://www.iea.org/weo/ [Access date: 9 May 2019].

7. International Energy Agency, Coal-fired power [Online]. Available: https://www.iea.org/tcep/power/coal/ [Access date: 9 May 2019]. 
8. 2011 Technology Map of the European Strategic Energy Technology Plan (SET-Plan) [Online]. Available: https://setis.ec.europa.eu/aboutsetis/technologymap/2011_Technology_Map1.pdf/view [Access date: 9 May 2019].

9. M.A. Gonzalez-Salazar, T. Kirsten, L. Prchlik, Renew Sust Energ Rev, 82, 1497-1513 (2018)

10. C. Chen, G.M. Bollas, Processes, 6(8), 114 (2018)

11. K. Burnard, S. Bhattacharya, International Energy Agency, 2011 [Online]. Available: https://www.iea.org/publications/freepublications/pu blication/Power_Generation_from_Coal2011.pdf [Access date: 9 May 2019].

12. A. Mirandola, A. Stoppato, A. Benato, Handbook of Clean Energy Systems, 6, 745-762 (2015)

13. M. Finkenrath, J. Smith, D. Volk, International Energy Agency, 2012 [Online]. Available: https://www.iea.org/publications/freepublications/pu blication/CCS Retrofit.pdf [Access date: 9 May 2019].

14. B.G. Miller, Clean Coal Engineering Technology (Second Edition), 261-308 (2017).

15. Integrated Gasification Combined Cycle IGCC [Online]. Available: https://www.globalgreenhouse-warming.com/integrated-gasificationcombined-cycle-IGCC.html [Access date: 9 May 2019].

16. Global CCS Institute - Chapter 1 Coal-fired Power Generation and Circulating Fluidized Bed Combustion (CFBC) [Online]. Available: https://hub.globalccsinstitute.com/publications/scopi ng-study-oxy-cfb-technology-alternative-carboncapture-option-australian-black-and-browncoals/chapter-1-coal-fired-power-generation-andcirculating-fluidized-bed-combustion-cfbc [Access date: 9 May 2019].

17. S. Seddighi, P.T. Clough, E.J. Anthony, R.W. Hughes, P. Lu, Appl Energy, 232, 527-542 (2018)

18. M.J. Ducker, Power Engineering, 119, 2015 [Online]. Available: https://www.powereng.com/articles/print/volume-119/issue8/features/the-fall-of-the-f-class-turbine.html [Access date: 9 May 2019]. 